$$
\text { DOE/FE- } 98004284
$$

\title{
MITIGATION ACTION PLAN \\ Sale of Naval Petroleum Reserve No. 1 (Elk Hills) \\ Kern County, California
}

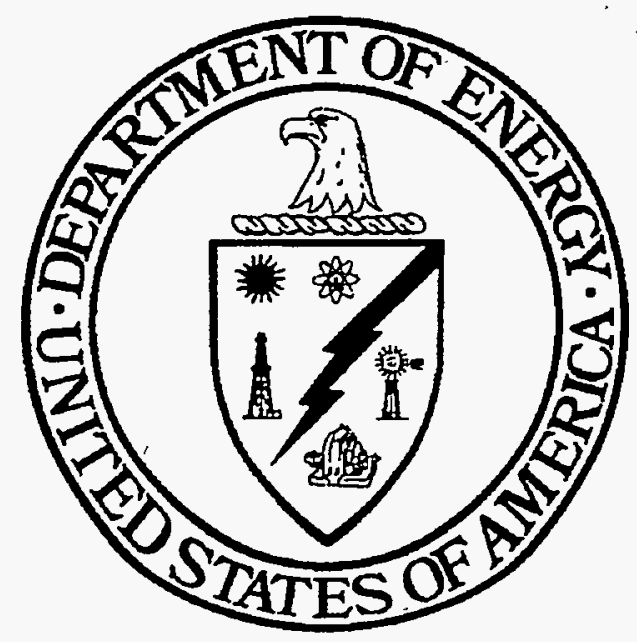

January 1998

\section{United States Department of Energy \\ Assistant Secretary for Fossil Energy \\ Naval Petroleum and Oil Shale Reserves}

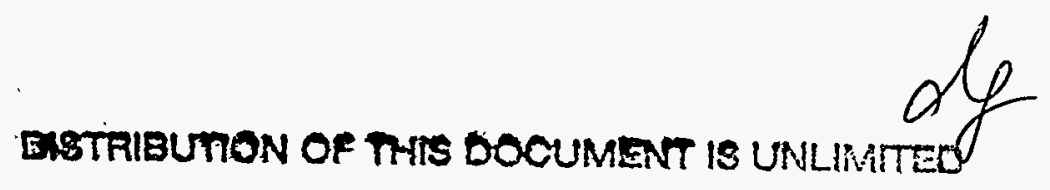




\section{DISCLAIMER}

Portions of this document may be illegible electronic image products. Images are produced from the best available original document. 


\section{Selected Acronyms}

\begin{tabular}{|c|c|}
\hline ARPA & Archeological Resources Protection Act \\
\hline BLM & Bureau of Land Management \\
\hline CAA & Clean Air Act \\
\hline CEQA & California Environmental Quality Act of 1970 \\
\hline CFR & Code of Federal Regulations \\
\hline CRMP & Cultural Resources Management Plan \\
\hline CWA & Clean Water Act \\
\hline DOE & United States Department of Energy \\
\hline DOI & United States Department of Interior \\
\hline EIS & Environmental Impact Statement \\
\hline ESA & Endangered Species Act \\
\hline FE & Office of Fossil Energy \\
\hline FONSI & Finding of No Significant Impact \\
\hline MAP & Mitigation Action Plan \\
\hline MER & Maximum Efficient Rate \\
\hline NAGPRA & Native American Graves Protection and Repatriation Act \\
\hline NEPA & National Environmental Policy Act of 1969 \\
\hline NHPA & National Historic Preservation Act \\
\hline NOSR-1 & Naval Oil Shale Reserve No. 1 \\
\hline NOSR-2 & Naval Oil Shale Reserve No. 2 \\
\hline NOSR-3 & Naval Oil Shale Reserve No. 3 \\
\hline NPOSR & Naval Petroleum and Oil Shale Reserves \\
\hline NPR-1 & Naval Petroleum Reserve No. 1 (Elk Hills) \\
\hline NPR-2 & Naval Petroleum Reserve No. 2 \\
\hline NPR-3 & Naval Petroleum Reserve No. 3 \\
\hline PEIR & Program Environmental Impact Report \\
\hline ROD & Record of Decision \\
\hline SEIS & Supplemental Environmental Impact Statement \\
\hline SHPO & State Historic Preservation Officer \\
\hline USFWS & United States Fish and Wildlife Service \\
\hline
\end{tabular}




\section{INTRODUCTION}

\subsection{History and Background}

Naval Petroleum Reserve No. 1 (NPR-1, also called "Ëlk Hills"), a Federally-owned oil and gas production field in Kern County; California, was created by an Executive Order issued by President Taft on September 2, 1912. He signed another Executive Order on December 13, 1912, to establish Naval Petroleum Reserve No. 2 (NPR-2), located immediately south of NPR-1 and containing portions of the town of Taft, California. NPR-1 was not developed until the 1973-74 oil embargo demonstrated the nation's vulnerability to oil supply interruptions. Following the embargo, Congress passed the Naval Petroleum Reserves Production Act of 1976 [Public Law (P.L.) 94-258], which directed that the reserve be explored and developed to its full economic potential at the "maximum efficient rate" (MER) of production. Since Elk Hills began full production in 1976, it has functioned as a commercial operation, with total revenues to the Federal government through FY 1996 of $\$ 16.4$ billion, compared to total exploration, development and production costs of $\$ 3.1$ billion.

In February 1996, Title 34 of the National Defense Authorization Act for Fiscal Year 1996 (P.L. 104-106), referred to as the Elk Hills Sales Statute, directed the Secretary of Energy to sell NPR-1 by February 10, 1998, unless the Secretary advised Congress that another course of action would be "in the best interests of the United States." The Secretary was also directed to study options for enhancing the value of the other Naval Petroleum and Oil Shale Reserve properties such as NPR-2, located adjacent to NPR-1 in Kern County; Naval Petroleum Reserve No. 3 (NPR-3) located in Natrona County, Wyoming; Naval Oil Shale Reserves No. 1 and No. 3 (NOSR-1 and NOSR-3) located in Garfield County, Colorado; and Naval Oil Shale Reserve No. 2 (NOSR-2) located in Uintah and Carbon Counties, Utah. The purpose of these actions was to remove the Federal government from the inherently non-Federal function of operating commercial oil fields while making sure that the public would obtain the maximum value from the reserves.

P.L. 104-106 required that the Department of Energy (DOE) prepare and submit a report to Congress regarding the management and disposition of Naval Petroleum and Oil Shale Reserve properties. The final report entitled "Report and Recommendations on the Management and Disposition of the Naval Petroleum and Oil Shale Reserves (Excluding Elk Hills)," dated March 1997, recommended that Congress enact legislation authorizing the transfer of most of the government's interest in NPR-2 to the Bureau of Land Management (BLM) in accordance with 
the Federal Land Policy and Management Act. This transfer would include possible leasing of the remaining unleased lands under the Mineral Leasing Act, with the exception of certain lots located in Ford City, California, which would be sold.

Operation of NPR-1 by a private entity could lead to faster development and different activities than those that would occur under continued government ownership. For example, a private owner might drill more wells and inject more water to force out increased amounts of oil. The additional wells would require more pipelines, access roads and other infrastructure within and outside the current area of operations of NPR-1. Therefore, DOE determined that the sale of NPR-1, as authorized by P.L. 104-106, is a major Federal action that may have significant impacts on the environment within the meaning of the National Environmental Policy Act of 1969 (NEPA). Further, the Kern County (California) Planning Department determined that the sale could have a significant effect on the environment within the meaning of the California Environmental Quality Act of 1970 (CEQA).

In October 1997, DOE and Kern County prepared a Final Supplemental Environmental Impact Statement/Program Environmental Impact Report (DOE/SEIS/PEIR-0158-S2) to address the requirements of NEPA and CEQA. The Proposed Action in the SEIS/PEIR is the sale of all of the Federal government's right, title, and interest in NPR-1 as directed by P.L. 104-106. As required by NEPA and CEQA, the document also examines alternatives to the Proposed Action, including the No Action Alternative, and analyzes cumulative impacts of the Proposed Action and alternatives when added to other past, present and reasonably foreseeable activities in the region. In addition, while the implementing regulations for NEPA only require the identification of mitigation measures, CEQA requires assurances that the feasible mitigation measures will be implemented before any State or local agency can approve the project. To meet this CEQA requirement, the SEIS/PEIR contains specific information on the implementation of mitigation. The Record of Decision (ROD) on the SEIS/PEIR for the Sale of Naval Petroleum Reserve No. 1 (Elk Hills), Kern County, California was published in the Federal Register on December 19, 1997, at 62 FR 66609-66616.

DOE's first EIS analyzing impacts of NPR-1 was issued in 1979 in response to the 1976 Naval Petroleum Reserves Production Act's requirement to produce oil at the maximum efficient rate. The 1979 EIS analyzed the environmental impacts resulting from the drilling, construction, operations and maintenance activities associated with developing the oil field. Major impacts 
addressed included land disturbances, waste generation and disposal, and air quality. A 1993 Supplemental EIS (1993 SEIS; DOE/EIS-0158) revised and updated the 1979 analysis and considered the impacts of several alternatives for further development for the oil field. In conjunction with the 1993 SEIS, the Department of Interior Fish and Wildlife Service (FWS) issued a Biological Opinion in 1995 describing mitigation requirements for protecting threatened and endangered species within NPR-1. The 1997 SEIS/PEIR is a supplement to the 1993 SEIS, which did not consider the sale of NPR-1. In addition to meeting the requirements of NEPA and CEQA, the document is also a floodplain/wetlands assessment for the Proposed Action, as required by the DOE Floodplain/Wetlands regulation, $10 \mathrm{CFR}$ 1022. The Proposed Action is not expected to have any significant impacts on this issue.

The two most important resource areas potentially impacted by the Proposed Action (as well as the No Action Alternative and the Alternative to the Proposed Action) are biological and cultural resources. The SEIS/PEIR also identified two other potentially significant resource areas for the three alternatives. These include air resources and water resources. Other potential resource areas and impacts analyzed in the SEIS/PEIR include geology and soils, hazardous waste, land use, noise, socioeconomics, energy conservation, and environmental justice. However, none of the impacts occurring in these areas were considered likely to be significant. The SEIS/PEIR concludes that all of the impacts resulting from the three alternatives could be mitigated to levels that are less than significant.

\subsection{Purpose of the Mitigation Action Plan}

Section 1021.331 of the DOE regulations implementing NEPA (10 CFR Part 1021) provides that:

(a) Following completion of each EIS and its associated ROD, DOE shall prepare a Mitigation Action Plan (MAP) that addresses mitigation commitments expressed in the ROD. The MAP shall explain how the corresponding mitigation measures, designed to mitigate potential adverse environmental impacts associated with the course of action directed by the ROD, will be planned and implemented. The MAP shall be prepared before DOE takes any action directed by the ROD that is the subject of a mitigation commitment.

(c) Each MAP shall be as complete as possible, commensurate with the information available regarding the course of action either directed by the ROD or the action to be covered by the Finding of No Significant Impact, as appropriate. DOE may revise the 
Plan as more specific and detailed information becomes available.

(d) DOE shall make copies of the MAP available for inspection in the appropriate DOE public reading room(s) or other appropriate location(s) for a reasonable time. Copies of the MAP shall also be available upon written request.

This MAP serves as a DOE program management document to address mitigation commitments expressed in the ROD and to explain how these measures will be planned and implemented. P.L. 104-106 requires that DOE conduct the sale of NPR-1 in a manner that maximizes the proceeds to the United States. Consistent with this objective, DOE has sought to ensure inclusion of mitigation measures in the Purchase and Sale Agreement for the sale of NPR-1 in a manner that does not reduce the eventual sales price.

First, the 1995 Biological Opinion (including all mitigation measures) will be transferred to the purchaser of NPR-1 through a provision of the sales contract pursuant to Section 3413(d) of P.L. 104-106. That section of the Act provides that:

"The Secretary [of Energy] may transfer to the purchaser or purchasers...the [Biological Opinion] incidental take permit...issued to the Secretary by the United States Fish and Wildlife Service and in effect on the effective date [of the Act] if the Secretary determines that transfer of the permit is necessary to expedite the sale of the reserve in a manner that maximizes the value of the sale to the United States. The transferred permit shall cover the identical activities, and shall be subject to the same terms and conditions, as apply to the permit at the time of the transfer."

DOE determined that the transfer of the incidental take permit would serve to maximize the value of the sale of NPR-1 to the United States. Accordingly, DOE included an optional provision in the draft Purchase and Sale Agreement for NPR-1, that was made available to all prospective purchasers, which would transfer the 1995 Biological Opinion (including the incidental take statement) to the purchaser(s) of NPR-1. That optional provision was accepted in the highest and best offer submitted by Occidental Petroleum Corporation (Occidental). By accepting the transferred Biological Opinion, Occidental:

“...assumes and agrees to be bound by and perform all of the Seller's [DOE's] obligations under the Biological Opinion, including the on-going monitoring requirements set forth in the Biological Opinion and the obligation to establish the conservation area specified in the Biological Opinion." 
Thus, Occidental will, through a provision of the sales contract, assume and be bound by all of the terms, conditions, and mitigation measures contained in the 1995 Biological Opinion and presently performed by and committed to by DOE.

The second step taken by DOE to incorporate mitigation into the sales contract was the inclusion of the following guidance to prospective bidders for NPR-1:

"You are advised that the Draft Supplemental Environmental Impact Statement/Environmental Impact Review \{sic\} (SEIS/PEIR) relating to the Elk Hills' sale was issued July 24, 1997 \{sic\}, and is available for your review. You should review the potential mitigation activities identified in that document in connection with submitting your Offer. To assist DOE in complying with its statutory obligations under the National . Environmental Policy Act, DOE requests that you consider including in your Purchase and Sale Agreement commitments to undertake mitigation activities such as those identified in the SEIS/PEIR provided that such commitments do not negatively impact your offered price(s) so DOE can comply with its statutory obligation to maximize sales proceeds."

In response to this provision, Occidental's offer to purchase NPR-1 contains the provision that it will:

"...work with Seller in good faith to deliver a list of mitigation measures to be implemented by Buyer after Closing....Buyer agrees to negotiate in good faith with the U.S. Fish \& Wildlife Service and the California Department of Fish and Game (or other relevant Governmental Authorities) prior to determining the specific mitigation, measures it will take...and to provide to Seller, within ten (10). business Days after Seller's issuance of the FSEIS, a list of such mitigation measures."

In compliance with this provision, on November 7, 1997, Occidental submitted a list of thirtythree (33) mitigation measures that it intends to implement following the transfer of NPR-1 to Occidental. In this letter, Occidental also identified the appropriate Federal, State, or local agency which is expected to monitor compliance with each of the measures. The mitigation measures submitted to DOE as a result of the offer by Occidental are referred to in the ROD.

\subsection{Organization and Content}

The MAP references the SEIS/PEIR and does not repeat or present in-depth technical information. However, the MAP does address the pertinent mitigation measures for which 
commitments were made in the ROD. The potential environmental impacts projected in the SEIS/PEIR were based on information from various technical engineering studies, as well as data related to specific issues obtained during previous NPR-1 oil field development activities. In the biological resources area, the analysis focused on the potential impacts of increased oil exploration and development activities under private ownership and operation of NPR-I. In the cultural resources area, the analysis focused on the potential impacts on archaeological resources including both historic and prehistoric sites.

As further details of specific mitigation actions are developed, the MAP will be revised to reflect the various administrative, implementation, reporting, and verification steps for those mitigation actions involving Federal and State agencies.

\section{IMPACTS and MITIGATION}

\subsection{Potential Environmental Impacts and Mitigation Measures}

NPR-1 is'expected to remain exclusively an oil field for at least the next half century. The differences in environmental impacts among alternatives are driven by the extent, timing and pace of development. Development by a private entity under the Proposed Action or the Alternative to the Proposed Action would likely occur sooner and be more intense than development by the Federal government under the No Action Alternative. The Proposed Action and DOE's Preferred Alternative, as stated in the ROD, is the sale of all the Federal government's right, title, and interest in NPR-1 as directed by the Elk Hills Sales Statute. Therefore, implementation of mitigation measures under the Proposed Action would be accomplished, for the most part, (except for the completion of certain mitigation measures related to cultural resources) by the proposed purchaser of NPR-1, Occidental, with enforcement by the Federal, State and local agencies that have regulatory responsibility for the activities occurring at NPR-1.

Potential Environmental Impact \# I - Biological Resources: There may be potential impacts from the Proposed Action and the resulting future development of NPR-1 on biological resources. NPR-1 serves as an important habitat for a number of threatened and endangered species, including the San Joaquin kit fox, the blunt nose leopard lizard, the giant kangaroo rat, the Tipton kangaroo rat, the antelope squirrel, and Hoover's woolly-star (a flowering plant). Oil and gas development on NPR-1 may continue to alter habitat and destroy or injure individuals of threatened and endangered species under the Proposed Action. Development 
under private ownership of NPR-1 is likely to be more intense than under continued government ownership and, consequently, have a greater potential for impact on plant and animal communities in general and on threatened and endangered species in particular. The impacts under private ownership from future development following the depletion of the reserves and the end of oil and gas production are too speculative to be predicted with any specificity. However, it is possible that additional stress to biological resources could occur, depending on how the owner(s) use the land.

Mitigation for Potential Environmental Impact \#1 - Biological Resources: The principal mitigation for the potential impacts on biological resources is Occidental's decision to accept transfer of and agreement to be bound by all the terms and conditions of the Biological Opinion and incidental take statement issued to DOE by the FWS on November 8, 1995. Those terms and conditions, including the mitigation commitments made by DOE, will be in effect until Occidental applies for and receives a new permit from the FWS under Section 10 of the ESA. A new Section 10 permit would contain appropriate terms and conditions agreed to by the FWS and Occidental. The principal mitigation measures contained in the 1995 Biological Opinion and which Occidental is obligated to implement include:

(1) Creation of a 7,075-acre conservation area and habitat management program;

(2) Conducting research, monitoring, and biological survey programs;

(3) Incorporation of a variety of measures to limit disturbance or destruction of individuals of threatened and endangered species during operation and construction activities;

(4) Prohibitions of public access, hunting, and livestock grazing within NPR-1; and

(5) Rèstrictions on the use of pesticides, herbicides, and rodenticides.

In addition to accepting the terms and conditions of the 1995 Biological Opinion, Occidental has entered into and will implement an Interim Memorandum of Understanding with the California Department of Fish and Game pursuant to Section 2081 of California's Endangered Species Act. The terms, conditions, and mitigation measures contained in this Memorandum of Understanding will mitigate potentially significant impacts on those "Covered" plant and animal species listed by the State of California. 
Potential Environmental Impact \#2 - Cultural Resources: Another resource area potentially impacted by the Proposed Action is cultural resources. Approximately 60 percent of the area of NPR-1 has been subject to archaeological survey and inventory. Based on knowledge of prehistoric site patterns, as well as historic and recent activities, DOE, in consultation with the California State Historic Preservation Officer (SHPO), determined that the amount and specific areas surveyed is sufficient and appropriate for determining the likely extent of significant cultural resources at NPR-1. There are three historic archaeological sites at NPR-1 that the SHPO has determined are eligible for inclusion on the National Register of Historic Places. There are also four prehistoric sites that are eligible for the National Register. DOE has completed its inventory efforts and it is possible that additional prehistoric sites may be determined to be Register-eligible. The documented prehistoric sites are represented by accumulations of flaked and ground stone, shell and bone artifacts, features, faunal dietary remains, and human bone fragments ( $\mathrm{a}$ human bone fragment and a potential human bone fragment at one site, and potential human bone fragments at a second site). These sites consist of artifacts that may be relevant to the prehistory of the area.

Discussions with the SHPO on prehistoric sites indicate that NPR-1 development may disturb the four individual prehistoric sites eligible for the National Register. In September 1997, DOE completed a survey of 3,000 acres previously unsurveyed, but predicted to be sensitive for prehistoric archeological resources. Archeological surveys and non-destructive identification activities at the most promising prehistoric sites within the 3,000-acre survey area were completed on January 21, 1998. The information produced from these activities will be used to determine the Register-eligibility of additional prehistoric sites.

Many potentially significant individual historic archaeological sites or buildings have been so disturbed so as to destroy their archaeological values. However, DOE recommended to the SHPO that NPR-1 be eligible for inclusion on the National Register as an historic landscape. The SHPO concluded that NPR-1 was not an historic landscape, but has found that three early production wells (the Hay No, 1, Hay No. 5, and Hay No. 7 wells) appear to be eligible for the National Register.

Mitigation for Potential Environmental Impact \#2 - Cultural Resources: Pursuant to Sections 106 and 110 of the National Historic Preservation Act (NHPA), DOE has executed a Programmatic Agreement with the California SHPO and the Advisory 
Council on Historic Preservation (Council) concerning research, data recordation, documentation and other preservation activities, as appropriate, to mitigate the impacts of the Proposed Action. As part of this process, DOE has considered comments from Native Americans and other members of the public. A set of prehistoric resources representative of the types found on NPR-1 would be treated by a combination of surface mapping, collection, subsurface excavations and analysis to recover data and to address important scientific research questions. A Cultural Resources Management Plan (CRMP) addresses the appropriate mitigation required to recover important data from these resources and to preserve it through appropriate documentation and publication. The CRMP is a part of the Programmatic Agreement. DOE will inform Occidental and the California Department of Conservation, Division of Oil, Gas, and Geothermal Resources that sites of the type where human remains have been found are known to exist in the area, although DOE will not provide the specific nature and locations of cultural resources in accordance with the Programmatic Agreement and Section 9 of the Archeological Resources Protection Act and Section 304(a) of the NHPA.

The Programmatic Agreement also addresses concerns related to NAGPRA. In developing the Programmatic Agreement with the SHPO and the Council, DOE has and will continue to provide for involvement and comment by Native Americans with traditional ties to Elk Hills and will repatriate or leave in situ, if so requested by Native Americans, any human remains which may be discovered, in accordance with NAGPRA. With respect to the three historic oil and gas wells that the SHPO has determined are eligible for the National Register, the Programmatic Agreement provides for a treatment plan to describe the historic context of these wells, as well as to publish the descriptions and distribute the descriptions to public libraries.

In addition to DOE's mitigation, the mitigation measures Occidental intends to implement include:

1. Evaluate inclusion of the two locations of suspected human remains identified by DOE within the conservation area to be established pursuant to the 1995 Biological Opinion;

2. Implement a cultural resources training plan supervised by an archaeologist; and

3. Implement a plan to address the discovery of suspected human remains, other than human remains addressed by the Programmatic Agreement between DOE 
and the SHPO, which may be unexpectedly encountered during construction activities. The plan may include consulting with the County Coroner, an archaeologist and/or a local Native American representative to avoid disturbing suspected human remains.

DOE also is in the process of finalizing a License Agreement with Occidental which would allow DOE and Native Americans to access Occidental lands for three years following the sale of NPR-1 to complete historic preservation activities.

Other Potential Environmental Impacts: Other resource areas potentially impacted by the Proposed Action are air quality and water resources. Future development of NPR-1 under the Proposed Action would likely result in higher levels of air emissions. Modeling of projected emissions for the year 2001, the highest expected emission year,, shows the potential that the State ambient air quality standards for $\mathrm{PM}_{10}$ (particulate matter 10 microns or larger) could be exceeded off-site. In addition, on-site Federal ambient air quality standards for $\mathrm{NO}_{2}$ (Nitrous Oxide) and State ambient air quality standards for $\mathrm{PM}_{10}$ and $\mathrm{SO}_{2}$ (Sulfur Dioxide) might be exceeded. However, these results are conservatively based on maximum permitted emission rates rather than likely lower actual emission rates, so the actual future emissions are expected to be within the National and State standards. The last resource potentially impacted from the Proposed Action is water resources. Accelerated commercial development under the Proposed Action would increase water use in the enhanced oil recovery technique known as "water flooding" and increase treatment and disposal requirements for "produced waters."

Mitigation for Other Potential Impacts: The impacts to these resources would be roughly proportional to oil production levels and can be mitigated through compliance with applicable National and State air emission standards and a continuation of the ongoing NPR-1 program to use treated produced waters in "water flood" projects. Occidental has committed to two mitigation measures with respect to air quality and fifteen (15) water resource mitigation measures. These mitigation measures by Occidental would continue these existing DOE practices.

- Other Resource Impacts: Additional areas of potential concern are geology and soils, hazardous waste management and disposal, land use, noise, socioeconomics, energy conservation, and environmental justice. Impacts in these areas are not likely to be significant. Comments 
received during scoping and comments received on the Draft SEIS/PEIR expressed concern that the possible loss of access to NPR-1 oil for use in local refineries and as a diluent for pipeline transmission could lead to a premature loss of local refinery production and/or the inability of local crude oil producers to deliver their products to market. Some local small and independent refiners and/or producers of heavy crude oil are dependent on continued access to the lighter NPR-1 oil, and concern was expressed that the proposed sale could limit their access to the oil. However, the proposed purchaser of NPR-1, Occidental, does not refine oil in California and is expected to put its share of the production from NPR-1 on the market. Therefore, small and independent refiners in the region should have access to NPR-1 crude oil under the Proposed Action (sale of NPR-1 to Occidental).

Mitigation for Other Resource Impacts: Occidental intends to implement 10 additional mitigation measures with respect to these other impact areas. In addition, all known hazardous waste sites at NPR-1 have been or will be remediated by DOE using appropriate remediation technology. However, remediated sites have, as yet, not received determinations that no further actions are needed from the relevant regulatory agencies. DOE will continue to work with these agencies to achieve final closure on the sites, including any additional mitigation work if required. In the unlikely event that any previously undiscovered reportable hazardous waste sites are encountered prior to the sale, DOE will characterize the contamination and disclose it to Occidental.

\subsection{Responsibilities for the Mitigation Measures}

There are three general areas of responsibility regarding the preparation and implementation of a MAP. First, the mitigation measures must be designed and developed, which includes the what, how, when, and where of the mitigation measure. The second area is mitigation implementation which covers the actual implementation of the mitigation measure. The party with primary responsibility for this area is the one that controls the execution of the mitigation measure. The third and last area of responsibility is mitigation verification and monitoring. This includes the act of verifying that the mitigation is accomplished in accordance with the plan. It includes the collection of activities that will be undertaken to determine if the mitigation measure is performing as intended (i.e., that it is producing the desired results or level of environmental impact mitigation), and, if not, to assist in determining what alternative measures should be taken. 
This MAP, as previously stated, is an internal DOE program management document to facilitate the completion of mitigation measures that DOE committed to in the ROD. The focus of this document is on DOE mitigation measures, and not the additional measures that Occidental intends to implement in partnership with other Federal, State and local agencies.

\section{MITIGATION SCHEDULE}

This section discusses the preliminary schedule for implementing the DOE commitments in this MAP. This schedule only addresses milestones and due dates for activities committed to by DOE. A mitigation measure schedule for commitments that Occidental intends to implement is not included in this document.

Continued site identification and evaluation work for determining eligibility on the National Register of Historic Places -- Completed as of January 21, 1998

Execution of the Cultural Resources Programmatic Agreement with the State Historic Preservation Officer and Council -- January 26, 1998

Transfer of the 1995 Biological Opinion issued by FWS -- Final Sale Date

Site identification, evaluation, and potential data recovery based on future site development plans by Occidental -- Final Sale Date through the following three years, as necessary 